\title{
THE Notion OF NATURAL NUMBERS AMONG GERMANIC MATHEMATICIANS DURING THE SECOND HALF OF THE $18^{\text {TH }}$ CENTURY
}

\author{
Elías Fuentes Guillén \\ Faculty of Sciences - UNAM - Mexico
}

(aceito para publicação em dezembro de 2018)

\begin{abstract}
While the idea of the naturalness of the positive integers is ancient, the idea of the naturals as the foundation of our number system is not. This latter idea, along with other factors, eventually led to the abstract definitions of natural numbers at the end of the $19^{\text {th }}$ century. But, what led to such an idea that was already present among Germanic mathematicians in the first third of the $19^{\text {th }}$ century? This article examines the tensions around the notion of number among the Germanic mathematicians of the second half of the $18^{\text {th }}$ century with the aim of contributing to a better understanding of some of the factors that explain the emergence of such a different approach to naturals.
\end{abstract}

Keywords: Natural numbers, $18^{\text {th }}$ century mathematics, irrationals, negative numbers.

\section{[A NOÇÃO DE NÚMEROS NATURAIS ENTRE MATEMÁTICOS GERMANICOS DURANTE A SEGUNDA METADE DO SÉCULO XVIII]}

\begin{abstract}
Resumo
Enquanto a idéia da naturalidade dos inteiros positivos é antiga, a idéia dos naturais como base do nosso sistema numérico não é antiga. Esta última ideia, juntamente com outros fatores, eventualmente levou às definições abstratas dos números naturais no final do século XIX. Mas, o que levou a essa idéia que já estava presente entre os matemáticos germânicos no primeiro terço do século XIX? Este artigo examina as tensões em torno da noção de número entre os matemáticos germânicos da segunda metade do século XVIII com o objetivo de contribuir para uma melhor compreensão de alguns dos fatores que explicam o surgimento dessa abordagem diferente para os naturais.
\end{abstract}

Palavras-chave: Números naturais, matemática do século XVIII, irracionais, negativos. 


\section{Introduction}

Within the arithmetic framework set by Abraham Gotthelf Kästner in his popular Anfangsgründe der Arithmetik, Geometrie, ebenen und sphärischen Trigonometrie und Perspectiv, the denomination 'natürliche Zahlen' was only used when he explained what a logarithm is (Kästner, 1758, p. 144). By contrast, in his posthumously published Paradoxien des Unendlichen, Bernard Bolzano referred to the "set [Menge] of all numbers (the so-called natural or whole [...])" (Bolzano, 1851, p. 20). These passages suggest that, while the idea of the naturalness of the positive whole numbers is ancient, somehow the denomination of these numbers as 'natural' became usual among Germanic mathematicians between the mid- $18^{\text {th }}$ century and the mid- $19^{\text {th }}$ century.

Later came the abstract definitions of natural numbers of Richard Dedekind (1888) and Giuseppe Peano (1889), in which ordinals were placed as the core concept, as well as others in which cardinals were so placed (cf. Corry, 2015, p. 249-262). But, even at that time, the struggles that characterized the $19^{\text {th }}$ century reconception of the ideas of 'quantity' and 'number' (cf. Ferreirós, 2007, p. 42) persisted. This was indeed highlighted by Dedekind, who wrote that, from the series of natural numbers, the "gradual extension of the concept of number [...] [could be attained] without any intrusion of foreign ideas (such as measurable quantities)" (Dedekind, 1888, p. X).

The terminology and ideas of Germanic authors such as Hankel, Kronecker, Grassmann, Bolzano and Gauss, all of them linked in one way or another to the development of the modern notion of number, account for that process of reconception. Examples of this are the term Zahlengrössen, used by Weierstrass and Cantor to refer to rational and irrational numbers (Cantor, 1872/1932, p. 97; Weierstrass, 1878/1988, p. 7, 8 $\& 40$ ), and the explicit conception of Martin Ohm of the -positive- whole numbers as the only numbers (Ohm, 1822, p. XI).

However, the Germanic notion of number that preceded such development has hardly been studied, with the exception of (Schubring, 2005) and some other works, such as (Bullynck, 2006) and (Confalonieri \& Kröger, 2016). In particular, what led to the approach to natural numbers that emerged among Germanic mathematicians by the beginning of the $19^{\text {th }}$ century? The analysis offered here on the configuration of the Germanic strict notion of number throughout the second half of the $18^{\text {th }}$ century addresses this question and, in doing so, aims to contribute to the previous studies in the subject.

While it is true that by the end of the $18^{\text {th }}$ century the receptivity of mathematical objects nowadays considered numbers was increasing among Germanic mathematicians, so it is that c. 1800 the tensions around the notions of number and quantity, coupled with pedagogical concerns, generated new foundational reflections. Indeed, those tensions could explain a minor detail in the mathematical literature of the time, namely the absence of the appellation 'natural numbers' in:

a) the entries 'Ganze Zahl' and 'Zahl' for the Mathematisches Lexicon of Christian Wolff (Wolff, 1747, p. 546 \& 1429-30); 
b) the entry 'Zahl' for Johann Heinrich Zedler's Grosses vollständiges UniversalLexicon (Zedler, 1749, p. 1145ff.);

c) the entries 'Ganz' and 'Zahl' for the Mathematisches Wörterbuch initially written by Georg Simon Klügel (Klügel, 1805, p. 309; Klügel et al., 1831, p. 1053ff.).

By contrast, it is stated both in the English Cyclopadia and the French Encyclopédie that the -positive- whole numbers, integers or "simply numbers" were also called "natural numbers" (Chambers, 1728, p. 641; Diderot, 1765, p. 202). As will be argued in this article, while the absence of that other denomination for positive integers in the aforementioned Germanic works could be related to their restricted notion of number, the point is that it was this notion that eventually contributed to the emergence of a different approach to the naturals.

First, a brief account of both the use of the term and the notion of natural numbers among authors linked to the French mathematical tradition of the second half of the $18^{\text {th }}$ century will be presented. While the particular traits of the conception of the naturals or 'simply numbers' within the Germanic mathematical tradition distinguish it not only from the French but also, for example, from the English, here focus is placed on the former because of the more explicit contrast between it and the Germanic during that period. Even though there were also differences within the French mathematical tradition regarding the conception of mathematical objects that urged broader notions of number and quantity (cf. Schubring, 2005), as will be shown, there was a certain consensus on these notions.

After discussing the basic notion of number among Germanic mathematicians by the mid- $18^{\text {th }}$ century, two sections are devoted to study a) the conception and treatment of numbers during the second half of the $18^{\text {th }}$ century, and b) some incipient changes towards the end of that century with respect to such treatment and conception. However, it is worth making a couple of remarks on methodological choices in this article.

On the one hand, it should be noted that the status of negative, rational and irrational numbers, as well as imaginary numbers and infinitely small quantities, posed a problem to $18^{\text {th }}$ century mathematicians that was already "very much present in the mind of seventeenth-century mathematicians and philosophers" (Mancosu, 1996, p. 85ff. \& 165ff.). Nevertheless, analysis is limited here to the first three types of those mathematical objects since, considered as the most immediate types of numbers introduced from the extension of the concept of the naturals plus zero, they are enough to account for the tensions around the notions of number and quantity.

Secondly, textbooks are used as basic sources that, along with some other works, offer a good panorama of the mathematics of the context and time addressed here. Even more, for this reason attention is paid especially -though not exclusively- to the works of authors who, being professors at the most important Germanic universities, had a greater impact on the new generations of mathematicians. While the analysis of a textbookcentered approach and the influence of those authors goes way beyond the scope of this article, further arguments than those sketched throughout the following sections are put forward in (Schubring, 2005), in favour of the former, and (Bullynck, 2013) and (Fuentes Guillén, 2017), in favour of the latter. 


\section{The term and the notion of natural numbers in the French mathematical tradition}

It is not just that the Encyclopédie accounts for an alternative denomination for 'whole numbers' among French authors of the time: it accounts for a conception that was widespread among authors linked in one way or another to the French mathematical tradition of the second half of the $18^{\text {th }}$ century. As a consequence, the term 'natural numbers' and its corresponding notion can be found in all sorts of publications ranging from the 1750s to the end of that century and from mathematical textbooks to articles published in the volumes of the Societas Privata Taurinensis (later Société Royale des Sciences de Turin), the Académie Royale des Sciences de Paris and the Académie Royale des Sciences et Belles Lettres de Prusse.

Several articles attest such a regular use, in some cases mentioning the 'nombres naturels' (Lagrange, 1759, p. 33; Saluzzo di Monesiglio, 1762, p. 122; Bernoulli, 1770, p. 390, 403 \& 407; Lagrange, 1770, p. 165-166; Laplace, 1776, p. 37), the 'progression des nombres naturels' (Euler, 1766, p. 59; Gerdil, 1774, p. 3) or the 'suite naturelle' or 'suite des nombres naturels' (de la Bottiere, 1763, p. 65; Rallier des Ourmes, 1763, p. 202 \& 222; Beguelin, 1775 , p. 210-214). In addition to which, in some specific cases the authors devoted a few lines to discuss the idea of natural numbers. For example, André-Pierre Le Guay de Prémontval argued that the specificity of 1 as a unit distinguished it from the rest of the terms in the sequence of natural numbers (1756, p. 425ff.), ${ }^{1}$ while Giacinto Sigismondo Gerdil argued against the consideration of that sequence as an 'actual infinite' (1762, p. 6-10 \& 23-33; cf. 1774).

On the other hand, textbooks that can be considered in that French tradition reaffirm the notion of the sequence $1,2,3,4,5, \& c$ as the most natural arithmetic progression. Indeed, throughout much of the second half of the $18^{\text {th }}$ century, the various expressions for natural numbers, although they were not exclusively used in a particular subject, were mostly associated with progressions and logarithms. That way, for example:

a) Charles Étienne Louis Camus, in his Élémens d'arithmétique, referred to the sequence of the natural numbers when explaining the multiplication table and mainly when discussing their logarithms (1749, p. 54, $403 \&$ \& 406), as he also did within the framework of plane trigonometry in his Élémens de géométrie (1750, p. $442-443,459 \& 470$ ), though not when studying the arithmetic progressions (1749, p. 365-380);

b) Nicolas-Louis de La Caille, in his Élémens d'algèbre et de géométrie, referred to the sequence of natural numbers within the framework of differential calculus, trigonometry and geometry (1741/1756, p. 268, $223 \& 212-213$, respectively), but it was in sections on progressions, logarithms and especially sequences, where he not only defined it as an increasing arithmetic progression, but as increasing to infinity, from 0 to what can be represented by the character $\infty$ (1741/1756, p. 92 , 104,116 \& 118-131);

\footnotetext{
${ }^{1} \mathrm{He}$ referred to it as a 'série', not a 'suite': "Je trouve la loi de continuité démentie dès le premier pas de la premiere \& de la plus simple de toutes les séries, celle des nombres naturels, 1, 2, 3, 4, 5, 6, \&c."
} 
c) Étienne Bézout, in his Élémens d'arithmétique, referred to the natural sequence of numbers within the section on logarithms (1764/1781, p. 217 \& 221), but not in the one on arithmetic progressions (1764/1781, p. 204-208), and, in the volume on algebra applied to arithmetic and geometry, within the section on arithmetic progressions (1766, p. 274-279);

d) Charles Bossut, in his Traité élémentaire d'arithmétique, referred to the natural numbers as the most simple of the arithmetic progressions in the section on logarithms and to the sequence of natural numbers in the final section on order changes and combinations (1772, p. $223 \& 262$, respectively), but not in the one on arithmetic progressions (1772, p. 164-173); while, in his Traité élémentaire d'algèbre, he constantly referred to the sequence of the natural numbers in the section on sequences (1773, p. 409-417);

e) Leonhard Euler, in his posthumously published L'Arithmétique raisonnée et démontrée, referred to the natural progression $1,2,3,4,5, \& c$ in the section on arithmetic progressions (1792, p. 405-408); while, in his Vollständige Anleitung zur Algebra, he referred from the very beginning to the "so-called natural numbers" $1,2,3,4,5$, \& so on to infinity (sogenannten natürlichen Zahlen) in the section on calculations with simple quantities $(1771$, p. 9, 49,64) and in the one on arithmetic progressions (1771, p. 185, 192-193), but not in the one on logarithms, although he associated the logarithms of positive numbers to the numbers $1,2,3,4,5, \& c(1771$, p. 95$) ;^{2}$

f) Bernoulli (Euler, 1774a, p. 48, $344 \&$ 353) and Lagrange (Euler, 1774b, p. 449, $484,510 \& 567$ ), in notes and additions to the French edition of (Euler, 1771), constantly referred to the natural numbers.

While the notion of number underlying that of the naturals, it must be said, was not only common in Europe, but also ancient (Elements, VII, def. 2), in the case of the French mathematical tradition the latter rested on particular assumptions with significant implications. This means, first of all, that despite their differences, all the mentioned authors concurred to consider 'number' as an assembly of several whole units that, in turn, was composed of parts (Camus, 1749, p. 1; LaCaille, 1741/1756, p. 3; Bossut, 1772, p. 1; Euler, 1792, p. 1). That way, whole and fractional numbers expressed quantities that consisted exclusively of whole units or exclusively or partially of aliquote parts of a unit, being represented in both cases by the digits $0,1,2,3,4,5,6,7,8,9$ plus, in the second case, a bar.

The notion of natural numbers, however, required a couple of further steps treated within the algebraic framework and not the arithmetic one. On the one hand, it required the

\footnotetext{
${ }^{2}$ Depending on the criteria used, Euler can be linked to both the French and the Germanic traditions. For example, one could take into account that he spent 25 years in Berlin, where he played an important role at the Prussian Academy of Sciences, to argue in favour of the second case scenario. However, his inclusion in this list is intended to stress his closer link to the former tradition within which, unlike what happened within the latter tradition, some of the algebraic ideas that he defended were not rejected. This approach differs from that of (Confalonieri \& Kröger, 2015), where the notion of negative numbers is discussed in most of the French textbooks mentioned here and the work of Euler is listed among the Germanic examples studied.
} 
introduction of negative numbers (Camus, 1749, p. 369; La Caille, 1741/1756, p. 39; Bézout, 1766, p. 78ff.; Bossut, 1773, p. 8; Euler, 1771, p. 8-9), since the 'positivity' of the numbers or whole numbers only arose once the distinction between positive and negative integers was established. On the other hand, it required a certain embracement of infinity in order to obtain the sequence of the most natural numbers, the whole ones, which, as Euler explained, grew to infinity by continuously adding 1 (Euler, 1771, p. 9-10).

So, even if, for example, sometimes negative numbers were introduced in the volumes devoted to arithmetic, their treatment strictly pertained to the algebraic framework (cf. Confalonieri \& Kröger, 2015), ${ }^{3}$ as Bézout pointed out in a footnote in his Élémens d'arithmétique (Bézout, 1764/1781, p. 231); and the same happened with the treatment of the infinite and, as shown above, with the explicit treatment of the sequence of the naturals. More importantly, in regard to negatives, the general idea was that they were negative quantities expressed by numbers, being called in some cases 'false' (faux, e.g. Camus, 1749 , p. 369) or 'negated' (verneinende, e.g. Euler, 1771, p. 9) but in many cases without further debate as to their status as numbers. While, in the case of the infinite, the usual trend was to embrace the infinite and accept both the infinitely large and small quantities, as well as different orders or species of them (La Caille, 1741/1756, p. 118ff.; Bossut, 1773, p. 197, 296; Euler, 1748 \& 1755). ${ }^{4}$

As will be explained in the following sections, the attitude among Germanic mathematicians of the time towards the negatives and the infinite was not the same, since their understanding of quantities and numbers was not like that of mathematicians linked to the French tradition. These notions shaped their particular way of doing mathematics during the second half of the $18^{\text {th }}$ century and, along with other factors, eventually contributed to the emergence of a different approach to naturals among Germanic mathematicians.

\section{The Germanic notion of number c. 1750}

By the mid- $18^{\text {th }}$ century, the Germanic mathematicians usually subscribed Christian Wolff's general ideas on mathematics, although there were discordant voices. Like him, most of them conceived mathematics as the "science of the quantities, that is, all those things that can be enlarged or shortened" (Wolff, 1716, p. 863); a characterization that was indeed similar to that of their French counterparts, for whom mathematics was those "sciences whose object is the magnitude or quantity", that is, "everything that is susceptible to increase and decrease" (La Caille, 1741/1756, p. 1).

\footnotetext{
${ }^{3}$ As Bernoulli explained in a footnote to $\$ 5$, where Euler identified analysis and algebra, some authors of the time, such as Bézout, distinguished between the method concerned with the general rules on numbers (analysis) and the instrument used by such a method (algebra) (Euler, 1774a, p. 4-5; Bézout, 1766, p. iij-iv).

${ }^{4}$ Both in the case of negative numbers and in the case of infinitely small quantities, Schubring offers some examples of French authors who rejected those notions during the second half of the $18^{\text {th }}$ century (cf. Schubring, 2005).

${ }^{5}$ La Caille's characterization not only emphasized the wide understanding of mathematics at the time (cf. Confalonieri \& Kröger, 2016, p. 2 \& 10-11), but also a more general understanding of 'quantity' when referring to "augmentation \& diminution" (cf. Bézout, 1764/1781, p. 1; Bossut, 1772, p. 5) instead of "vergrössern oder verkleinern", as Wolff did. In the corresponding dictionary entry, however, the latter defined 'quantitas' or
} 
Numbers, on the other hand, were defined by Wolff in a wide sense, as "that which is related to the unit like a straight line to another one" (Wolff, 1713, p. 21-22; 1716, p. $945 ; 1742$, p. 24) and, in a narrow sense, as "the aggregate of similar single things" (Wolff, 1710 , p. 34). The latter definition clearly resembles the traditional one, and thus that prevailing in the French tradition, within which the definition of Joachim Georg Darjes (professor at Jena) as "that which expreses the units in a quantity" was also usual (Darjes, 1747, p. 73; cf. Bézout, 1764/1781, p. 2). But, regarding the first of Wolff's definitions, it resembles an alternative definition that can be found, for example, in Newton's work (Newton, 1707, p. 2), as well as in the work of some of Wolff's own contemporaries, such as Christian Hausen (professor at Leipzig) (cf. Hausen, 1734, p. 2).

As Wolff stressed, his "general" -relational-definition fitted both the rational and irrational numbers. Therefore, he defined a 'whole number' as that "related to the unit as the whole to one part", a rational as "that composed either of units or of aliquote parts of the unit" ("whose unit is commensurable", "also called describable"), and an irrational as "that without a rational proportion to the unit" ("whose unit is incommensurable", "also called indescribable, as well as geometrical”) (Wolff, 1713, p. 24; 1716, p. 953 \& 965; 1742, p. 27).

Precisely, in the arithmetic framework set in his Elementa Matheseos Universa, Wolff added a scholion explaining that the treatment of irrationals pertained to geometry and analysis (Wolff, 1713, p. 66). After all, in the strictest sense of the expression, the irrationals were not numbers. That way, in the geometric framework he mentioned the diagonal of the square as an irrational number (Wolff, 1713, p. 175), while in the analytical one -of finite quantities- he introduced the irrationals' arithmetic, after stating that irrational quantities could be expressed by means of rationals (Wolff, 1713, p. 257; cf. 1716, p. 179).

Such an understanding of the irrationals as imperfect or non-finite expressions linked to geometry and analysis was not strange within the French (La Caille, 1741/1756, p. 97 \& 173; cf. Bézout, 1766, p. 128; Bossut, 1773, p. 269) and Germanic traditions. So, even though Hausen included the definition of irrational numbers among the basic ones of arithmetic, consisting of numbers that could not be measured by the unit or any part of the unit, they were strictly considered quantities not to be treated in arithmetic, as he remarked (Hausen, 1734, p. 3).

In fact, similarly to Wolff's stance, Darjes introduced the notion of 'irrational quantities' when writing about roots, where he explained that irrationals could not be obtained exactly and, therefore, in calculus the irrational numbers had to be transformed into decimals (Darjes, 1747, p. 134). After which, Darjes introduced a section on irrationals' arithmetic, which, as in Wolff's work, mainly consisted of problems and their solutions (Darjes, 1747, p. 148ff.).

The attitude within the Germanic tradition towards negative numbers, nonetheless, was quite different from those ascribed to the French tradition. Certainly, in his mathematical dictionary, Wolff did not include negatives among the 'numbers' but only as

'Grösse' as that capable of "vermehren und vermindern" (increase and decrease) (Wolff, 1716, p. 1143; cf. Cantù, 2003, p. 119-121). 
a special kind of 'quantities', namely "negative, privative or less than nothing" quantities, and even "the lack [Mangel] of a quantity" (Wolff, 1747, p. 608 \& 1429-1430; 1717, p. 1148). But, for him, the negative quantities not only were not real (wirckliche), as were the positive ones, but neither could they be in ratio with the latter, being of different kinds (ibid., p. 608). That is why, when he introduced the notion of 'negative quantities' in the analytical framework of finite quantities set in his Elementa, he insisted on the impossibility of such a ratio since, he wrote, they were heterogeneous kinds of quantities (1713, p. $247-248 ; 1742$, p. $299-300 \& 26)$.

Wolff's conception of negative quantitites was not strange among Germanic mathematicians. In his Introductio to logic, for example, Darjes referred to the impossibility of combining heterogeneous positive and negative or privative things (Darjes, 1742, p. 1518). However, in a work on the first grounds of mathematics published five years later, Darjes introduced both positive and negative quantities at the beginning of the arithmetic framework, as well as operations between them, without assuming that this involved an ontological commitment (Darjes, 1747, p. 86ff.). And, similarly, when Hausen introduced negative quantities within the arithmetic framework in his Elementa Matheseos, he explained operations with them, denoted by letters and numbers, and wrote that they were of the same kind (generis) as the positive ones (Hausen, 1734, p. 13ff.; cf. Schubring, 2005, p. 98).

Moreover, along with that sort of implicit criticism of Wolff's conception of negative quantities, there was also direct criticism of it. In a work on algebraic equations published in 1752, Franz Aepinus (professor at Rostock) pointed out that negative quantities were "true and real quantities" (Aepinus, 1752, p. 15), a subject to which he even devoted a paper a couple of years later. There, he was critical of the usual treatment of negative quantities and drew attention to the difficulties that it entailed for beginners (Aepinus, 1754, p. 5). Among others, he mentioned Darjes and Hausen, even pointing out the trading approach of the first and the latter's example of the rise and fall of the sun compared to the horizon (ibid., p. 5-8; cf. Hausen, 1734, p. 13), but above all he mentioned Wolff, whom he criticized throughout his work. For Aepinus, one should not distinguish between positive and negative quantities as different kinds (species) but, in any case, as ways of conceiving quantities: "it is not correct to say that quantity is negative or positive, but it is better to say that it is conceived or viewed as positive or negative" (Aepinus, 1754, p. 8).

So, despite the fact that in practice Wolff contravened his own conception of negative quantities, as Gert Schubring has pointed out (Schubring, 2005, p. 96-97), his insistence on the conceptual distinction between positive and negative quantities, as well as the discussion on that issue in the works of his Germanic contemporaries, reflect a particular debate missing at the time -at least that way- within the French tradition. As will be discussed in the following sections, that debate intensified among the following generations. 


\section{The Germanic panorama in the second half of the $18^{\text {th }}$ century}

Throughout the second half of the $18^{\text {th }}$ century, Göttingen became the most modern Germanic university and, along with Halle, the academic and administrative model for many other Germanic universities (cf. Paulsen, 1906, p. 47; Ash, 2006). At that time, therefore, math teachers at those institutions were highly influential among new Germanic mathematicians. Furthermore, even though at the Académie Royale des Sciences et Belles Lettres de Prusse there were "first-class mathematicians [...] and eminent mathematical research" was done (Knobloch, 1998, p. 1), some of their core notions and practices were commonly perceived as alien and were even explicitly rejected. On the contrary, it was the works of Johann Andreas von Segner, Wenceslaus Johann Gustav Karsten and especially Abraham Gotthelf Kästner, the math teachers at the aforementioned universities, that at the time influenced the mathematicians within the Germanic territories.

Undoubtedly, those three authors grew up during the heyday of Wolff's influence, like the rest of the Germanic ones of the mid- $18^{\text {th }}$ century. But, when studying their works, it must be taken into account where and therefore with whom they studied. So, while Segner studied at Jena in the early 1730s and Kästner at Leipzig (with Hausen) in the late 1730s, that is, at two of the most important universities in the Germanic territories at the time, Karsten studied temporarily at Jena (with Darjes) and mainly at Rostock (with Aepinus) in the early 1750 s, a university that was important only in a regional context.

It is true that, broadly speaking, the notion of 'numbers' among those authors and their contemporaries might seem the same as that of their predecessors when reading their works. Firstly, the notion of 'number' as an aggregate remained common: Segner referred to it as a "concept [of the conjunction of things] that arises from the unit" or, as he wrote in his last work, "from the repetition [Wiederholung] of the unit" (Segner, 1747, p. 2-3; 1773, p. 4; cf. 1756, p. 3; see also Büttner, 1754, p. 14 \& 16); Kästner called it "a multitude [Menge] of things of the same kind [or units]" (Kästner, 1758, p. 21-22; cf. 1800, p. 24-25); Karsten considered it "an aggregate [complexum] of homogeneous [things or units]" or the "joint counting [zusammengezählten] of several things of one kind" (Karsten, 1756, p. 12 \& 14; 1780, p. 3-4); and Johann Christian Ludwig Hellwig (teacher at Braunschweig) conceived it as a "character by which the units of a quantity are represented [ausgedruckt]" (Hellwig, 1777, p. 63).

Secondly, they all defined broken or rational numbers as those that arose by dividing the unit into equal parts and considering some of them, and irrationals as numbers that could not be expressed by whole units and parts of the unit. Precisely, the usual appellation "incommensurable" accounted for such impossibility, just as unausprechliche (Segner, 1747, p. 162; ineffabiles in Büttner, 1756, p. 113), stumme (Büttner, 1754, p. 98) or surdi (Kästner, 1758, p. 102; 1800, p. 115; surdische in Hellwig, 1777, p. 181), that is, 'mute', accounted for their inexpressible character by a finite number of digits. Those names were used to refer to them, as Büttner wrote, since such numbers can never be obtained with full precision and, therefore, reason could never fully grasp them (Büttner, 1756, p. 113).

As a consequence, Segner argued that the irrationals led to a different notion of 'number' that, as he himself recognized, was closer to the geometric magnitudes (Segner, 
1747, p. 163). Within the arithmetic framework, irrationals basically appeared in the sections on roots and geometric proportions, while they were mainly used throughout the geometric and algebraic or analytical frameworks. This is the case of Segner (cf. $1756 \&$ 1758), Büttner (cf. 1754 \& 1756), Kästner (cf. 1758/1800 \& 1761/1770); Karsten (1768b \& 1780) and Hellwig (cf. 1777). Thus, for example, Kästner said in the geometric section on the calculation of figures that the simplest case of an irrational number was $\sqrt{2}$, the diagonal of a square with side $=1$ (Kästner, 1758, p. 255). As he went on to explain, in this case geometry achieved a determination that was unattainable for arithmetic (ibid., 255-256).

The physical-geometric roots of the extensions of what was considered the correct notion of number can indeed also be noticed, for example, in Segner's didactics when introducing the broken numbers: "To make all this even clearer", he said, one should consider a straight line and the equal segments into which it could be divided (Segner, 1747 , p. 4). But, above all, those roots can be noticed in the way in which some authors introduced the negative quantities and numbers. Segner himself, for example, in the first edition of his textbook introduced negative quantities and numbers (without naming them as such) within the framework set in the section "Grounds for the calculation with extended quantities", an application of numbers for the resolution of geometric problems (Segner, 1747, p. 646 \& 656-657; cf. Schubring, 2005, p. 132-133). More clearly, when Karsten introduced those notions within the analytic framework, he exemplified them by the flow (fluat) of a point in a straight line from negative to positive values or vice versa (Karsten, 1760, p. 272; cf. 1758, p. 22-27).

In addition to this, the case of the negatives reveals the Germanic conceptual problematic regarding the numbers. In the Germanic textbooks, more often than in French, the notions of negative quantities and numbers were introduced within the arithmetic framework, even though they were still strongly linked to the algebraic framework. Thus, when at the beginning of the arithmetic framework Büttner pointed to the case in which a larger number was subtracted from a smaller, resulting in one less than nothing or 0 , he added that this was a kind of subtraction common in algebra (Büttner, 1754, p. 19; cf. Euler, 1771, p. 10). So, it was in his volume on algebra where he defined the negative quantities as those that did not correspond to something that actually existed but to an absence (Mangel), along with which he made some significant remarks:

a) Negatives were "relative quantities", since they arose from the denial of one of two opposite quantities;

b) they were also called "privative", "less than nothing", "incongruous" (absurdas), "imaginary" and "false" quantities;

c) the notion of the negatives was usually illustrated, as he said and did, by the debt;

d) and, he included a reference to an excerpt of Aepinus' work on the notion of negative quantities. (Büttner, 1756, p. 13-14)

It must be stressed that, generally speaking, negative numbers were conceived as numerical adscriptions of negative quantities and that the common procedure among these authors was to treat them within the algebraic or analytical framework, despite sometimes 
being introduced within the arithmetic one (cf. Confalonieri \& Kröger, 2015). Both their treatment in (Segner, 1747, p. 656-657) and (Karsten, 1760, p. 271-272), for example, was done within an analytical framework, although in the case of the former this changed in the second edition. There, Segner modified the 'arithmetic' section on the designation of quantities that augmented and diminished each other, so that the signs + and - were no longer only linked to those processes, but also considered as signs that designated quantities and their numbers (Segner, 1747, p. 26-28; 1767, p. 27-28).

Something similar to what Segner proposed by that amendment can be said about where and how the notion of negatives appeared in the works of Kästner and Hellwig. As for the latter, he based those quantities -and implicitly numbers- on the relation of opposition (entgegen gesetzte) and he introduced them in the 'arithmetic' section on the general properties of the formation of quantities by calculation (Hellwig, 1777, p. 69). While, analogously to Hellwig albeit explicitly, Kästner introduced negative numbers in the 'arithmetic' section on opposite (entgegengesetzten) quantities (Kästner, 1758, p. 59ff.; 1800 , p. $71 \mathrm{ff}$.). As this in turn makes clear, the notion of 'oppositeness' was central to the conception of the negatives (cf. Segner, 1767, p. 27; Büttner, 1756, p. 13; Karsten, 1760, p. 272; 1768b, p. 64; 1786, p. 210-211; cf. Schubring, 2005, p. 132ff.).

More importantly, such a notion accounted for the relational character of positive and negative quantities and, therefore, numbers. On the one hand, for them negative quantities -and numbers- were relative, as Büttner wrote and as Kästner emphasized when he explained that just as debt was the denial of assets, the latter could be considered the denial of debt (Kästner, 1758, p. 59-60). Which, ultimately, meant that positive and negative quantities and numbers, though different in a certain sense, were "homogeneous" (Kästner, 1739, p. [32]) or were "not of a different kind" (Segner, 1747, p. 646; 1767, p. 639). Hence the insistence of both Kästner and Karsten to point out that the error of some authors, such as Wolff, had been to assume that the designation referred to the actual nature of the things (cf. Karsten, 1786, p. $241 \&$ 207), that is, not to "distinguish between signs and things" (Kästner, 1759, p. [16-17]; cf. 1758, p. 61-62). ${ }^{6}$

On the other hand, the mere denominations used by the Germanic authors to refer to negatives hinted their understanding of them. Undoubtedly, as Karsten said, some of those expressions should be understood as "technical terms" (Kunstwörter) and not be interpreted strictly (Karsten, 1786, p. 241). But, not by chance, along with 'negative' and 'privative', the most frequently used denomination was precisely that of 'negated' or 'denied' (verneinte) quantities and numbers (cf. Büttner, 1756, p. 13; Kästner, 1758, p. 59; Karsten, 1768b, p. 67; 1768a). As Karsten himself repeatedly said, although all those names were commonly used, negative and positive quantities should properly be called "denyingly [and] positively expressed" (verneint and positiv ausgedrückte), respectively (Karsten, 1768a, p. 8; 1768b, p. 67; 1786, p. 211; cf. Schubring, 2005, p. 136-138).

\footnotetext{
${ }^{6}$ This passage pertains to the "Considerations" that Kästner wrote at the beginning of a textbook on analytic geometry authored by Johann Michael Hube, a student of the former. The discussion of the development of that area during the second half of the $18^{\text {th }}$ century goes beyond the scope of this article, but it should be noted that, as Schubring wrote, it "can indeed serve as a particularly illustrative indicator for the degree of acknowledgment and operativity of negative numbers" (Schubring, 2005, p. 135).
}

RBHM, Vol. 19, no 37, p. 1-23, 2019 
Just as in the case of the irrationals, therefore, the discussion about the negatives highlighted the idea that numbers were, strictly speaking, the - positive- whole ones, to which zero was added and from which the rational numbers could be formed. Karsten even went so far as to point out that, as a matter of fact, the distinction between whole and broken numbers was "not founded upon the nature of the numbers themselves" (Karsten, 1767 , p. 3). So, while the idea of naturalness underlay the notion of positive integers, within the arithmetic framework they were not called 'natural numbers' but assumed so (cf. Kästner, 1758, p. 144). Indeed, it was not until the fourth edition of his Anfangsgründe der Arithmetik when Kästner added a sort of historical note in which he traced back to Aristotle the idea of "the numbers of the fingers" as the "most natural" numbers, quoting a text from the early $17^{\text {th }}$ century as a reference on the subject (Kästner, 1786a: 27); ${ }^{7}$ an addition that, in some way, suggests an increasing use of that denomination by the $1780 \mathrm{~s}$.

Nevertheless, the treatment of negatives and irrationals by some of those Germanic authors shows a certain receptivity towards those 'numbers', while still struggling with them because of the prevalent notions of quantity and number. A common claim among them was that negatives and irrationals were "real" quantities and numbers, unlike those known as imaginary, which were "impossible" (cf. Segner, 1758, p. 242-243; Karsten, 1760, p. 336). In spite of which, as mentioned before, the former could only be understood as numbers within a wider notion of number. In some cases, this occurred within the algebraic or analytic framework. Furthermore, sometimes it was pointed out that irrationals could be approximated by a sequence of fractions, though strictly speaking they could not be instantiated numerically but only geometrically; while, on the other hand, sometimes negatives were explicitly linked to the transition from positive to negative points on a line.

However, just as in his last works Karsten left aside an eminently geometric presentation of negative numbers (cf. Karsten, 1781, p. 189ff.; 1786, p. 205-206), the works of other authors also make clear a certain transition that at the time was taking place. This is the case of, for example, the works of those authors who introduced both negative and irrational numbers within the arithmetic framework. One of them, Kästner, devoted the first chapter to whole numbers (plus basic operations with them), powers, fractions (plus basic operations with them) and negatives (plus their arithmetic), and treated irrationals three chapters later, when explaining the extraction of the square and cubic root (Kästner, 1758/1800). Another one, Hellwig, introduced whole numbers, then negatives, then the basic operations with both of them, then fractions and basic operations with them and then, in the chapter on root extraction, he treated irrationals (Hellwig, 1777).

It should be noted that at the time there was no attempt to provide a more careful definition of positive integers than the usual definition of 'numbers'. What at most can be found are characterizations or intuitive presentations of natural numbers, as in the case of Kästner. Thus, in a section on the sum of arithmetic series within a volume on applications of arithmetic, Kästner stated that the simplest example of arithmetic series was the one of

\footnotetext{
${ }^{7}$ Although a copy of the third edition of 1774 has not been examined, it is highly probable that it does not contain this addition since an alternate edition published in Wien in 1783 does not contain it (cf. Kästner, 1783, p. 27), while the latter does contain other modifications with respect to the second edition. In addition to this, it should be noted that the text quoted by Kästner was already mentioned in his volume on the analysis of the infinite quantities (cf. Kästner, 1761, p. Vorrede [15]).
} 
"affirmed natural whole numbers, whose first member is $=1$ [and whose] difference is also $=1$ " (Kästner, 1786b, p. 41).

Finally, although a detailed appraisal of the Germanic understanding of quantity at the time goes beyond the scope of this paper, it is worthwhile to draw attention to the widespread rejection of the notion of infinitely small quantities as variable quantities that could be identified with 0 . Faced with the rise of Euler's differentials (cf. Euler, 1755) within the French tradition, Germanic authors insisted on the fact that, if the word 'quantity' was to be taken rigorously, not only no quantity could be $=0$ (contradictory), but no 0 could be smaller than another (absurd) (cf. Segner, 1747; Karsten, 1758, 1768b, 1786; Kästner, 1783, 1786a; cf. Aepinus, 1752; Darjes, 1747).

The explicit criticism of Kästner (1758, p. 17) and Karsten (1786, p. 249-250) on the lack of rigour and the deviation within the French mathematical tradition, therefore, indeed reflected the discrepancy between their respective notions of quantity and number (cf. Bullynck, 2006, p. 5). Nonetheless, as will be argued in the final section, by the end of the $18^{\text {th }}$ century and the beginning of the $19^{\text {th }}$ century, the tensions around those notions, coupled with other factors, paved the way towards a different approach to the domain of natural numbers among Germanic mathematicians.

\section{Final remarks: The Germanic notion of number c. 1800}

One of the best Germanic sources -if not the best- on the terminology used in mathematics by the beginning of the $19^{\text {th }}$ century is the aforementioned mathematical dictionary of Klügel (former student of Kästner, prof. at Helmstedt and Halle). After his death in 1808, the same year that the third volume of his work was published, the project was continued to completion by Carl Brandan Mollweide (former student of Pfaff) and Johann August Grunert (former student of Pfaff and -briefly- Gauss). ${ }^{8}$ This is relevant here not only because the entry 'Zahl' was published without Klügel's supervision, but also because it appeared more than two decades later, in 1831. And yet, while the division of the "whole science of numbers" into arithmetic and number theory accounts for a change that occurred during those years (Klügel et al., 1831, p. 1057), the notion of number as including whole and rationals makes evident the prevalence of conflicts around it.

In Klügel's dictionary numbers par excellence (schlechthin) were the -positivewhole, understood as those formed by the multiplication of the unit and 'number' as a multiplicity of similar things that could or could not be named (Klügel et al., 1831, p. 10531055). As the authors went on to explain, the reverse process, that is, the division of the unit, led to obtaining the broken numbers. That way, the definition of number and the exclusion of negatives and irrationals were consistent with the stance of Klügel himself, both in the previous volumes of the dictionary and in other works. In his book on the groundings of arithmetic, for example, he defined 'number' as 'the idea [Vorstellung] of the form of a multiplicity of similar things" (Klügel, 1792, p. 7) and he only introduced the

\footnotetext{
${ }^{8}$ The advisor of Gauss at Helmstedt was precisely Johann Friedrich Pfaff (former student of Kästner), who in his inaugural dissertation clearly asserted that, in a way, it was "permissible to equal to 0 the differentials of variable quantities" (Pfaff, 1788, p. 5), openly rejecting in that way the opinion firmly defended by many of his predecessors (cf. Dhombres, 1995).
}

RBHM, Vol. 19, n 37, p. 1-23, 2019 
irrational and negative numbers to say that: a) the quantity of the former could only be accurately represented in geometry and b) the members (numbers) of the arithmetic progression, if read backwards, would lead to "negated" members (Klügel, 1792, p. 31 \& 50-51). While, in his dictionary, he introduced negative numbers when talking about opposite quantities and defined irrational quantities as a "proportional concept" for quantities (Klügel, 1805 , p. 104ff. \& 949, respectively). ${ }^{9}$

Perhaps of those notions discussed here, that on whose status there was a broader consensus was that of what we nowadays call 'imaginary numbers': imaginaries were not numbers, despite being called so sometimes, and indeed they were not even quantities but, in any case, "impossible quantities" that were "only useful on behalf of analytical calculus" (Langsdorf, 1802, p. 83; Raupach, 1815, p. 75; Schultz, 1788, p. 234; cf. Zimmermann, 1805 , p. 292). Indeed, in his dissertation of 1799 , Gauss was critical both with that terminology and with the conception underlying it (cf. Gauss, 1799, p. 5-7). But even a few decades later there was still some reluctance towards imaginary quantities and, for example, Bernard Bolzano (1810, p. 30-31; 1816, p. 144), Augustin-Louis Cauchy (1821, p. iij-iv \& 173ff.) and Josef Ladislav Jandera (1830, p. XXIX; professor at Praha) preferred to refer to them as "expressions" (imaginärer Ausdrücke and expressions imaginaires) instead of quantities.

Irrational numbers, on the other hand, continued to be commonly used but at the same time their status still posed some conceptual problems for several authors within the Germanic tradition. The impossibility to express them numerically -with absolute precision- led some authors to explicitly state that irrationals were not numbers but, simply, quantities. Because of that, for example, Immanuel Kant defended in a letter of 1790 that $\sqrt{2}$ was not a number (cf. van Atten, 2012), while Bernhard Friedrich Thibaut (former student of Kästner, professor at Göttingen) said that expressions such as $\sqrt{7}$ should not be called numbers (Thibaut, 1809b, p. 84).

Nevertheless, since irrationals could be approximated by fractions, it was increasingly frequent to find authors who emphasized that, since what applied for the rationals and ultimately for the whole numbers could in turn be applied to the irrationals, the status of these latter as 'numbers' was thus guaranteed (Langsdorf, 1802, p. 103; Zimmermann, 1805, p. 217). Even more, in the case of the Anfangsgründe der reinen Mathesis of Johann Friedrich Schultz (professor at Königsberg), a section on irrational numbers was included just after the ones on broken numbers and decimal fractions, in contrast to the usual practice (cf. Schultz, 1790, p. 105). There he defined irrationals as a sort of infinite fractions and, after that section (the last on types of numbers), he went on to explain in another section the "numbers in general", that is, the whole, rational and irrational numbers (Schultz, 1790, p. 110).

\footnotetext{
${ }^{9}$ Klügel wrote a couple of essays on the opposite quantities, which were published in 1795 and were praised among his contemporaries. Gert Schubring suggests that "Klügel's concept was contradictory" (Schubring, 2005, p. 139), since he both disqualified the English mathematicians for their-general- rejection of negative quantities and, at the same time, he considered that this notion was unnecessary for the rules of algebra's common operations (Klügel, 1795a, p. 316; 1795b, p. 479). From our perspective, Klügel's approach indeed denotes the prevailing geometric roots of the notions of quantity and number and the tensions around them.
} 
Coupled with that, the treatment of negatives in the work of Schultz makes patent other ongoing important changes. He was both careful with the name, referring to "opposite quantities and numbers", and with the placement of the corresponding section, namely, after the above mentioned section on numbers in general (cf. Schultz, 1790, p. 120). In other words, he was not only replacing the approach of previous generations when explicitly referring to negative numbers within the arithmetic framework, but he was also pointing out the need to pay more attention to the mathematical terms and concepts used, as well as their concatenation. As the rest of his work shows, this was related to his foundational concerns, for which precisely Bolzano, in his 1810 work on the foundations of mathematics, mentioned him as an important predecessor in such endevour (cf. Bolzano, 1810, p. 9).

The fact that Schultz still warned against considering the negative quantities as unreal or defective (Schultz, 1790, p. 126-127) and Thibaut used the name "conflicting numbers" (widerstreitenden Zahlen) in his Grundriss der reinen Mathematik (Thibaut, 1809b, p. 57), sustains Bolzano's inclusion of that concept, along with those of "imaginary expressions" and "the irrationality of a quantity", among those awaiting further clarification (Bolzano, 1816, p. 143-144). But, at the same time, the works of Thibaut and some other contemporaries of Schultz highlight the presence of those foundational and even pedagogical concerns.

Thibaut criticized the foundation of arithmetical theories on geometrical considerations (Thibaut, 1805, p. 168) and the use of "extraneous principles" that contravened the purity of analysis (Thibaut, $1809 \mathrm{a}, \mathrm{p}$. IV). Around the turn of the $18^{\text {th }}$ century and throughout the first third of the $19^{\text {th }}$ century, similar claims on methodological and foundational issues concerning analysis and arithmetic can be found in, for example: a) Lagrange's criticism of Newton's theory of fluxions for introducing a "foreign" idea (motion) in a calculation of algebraic quantities (1797, p. 4); b) Bolzano's insistence that geometrical concepts should not be used to prove purely arithmetical truths, since no proof should make use of concepts alien to it, just as no science should make use of concepts of a less fundamental science (1804 p. IVff.; 1810); c) Bolzano's "purely analytic" procedures (1817a; 1817b, p. VI); and d) the attempt of Martin Ohm (former student of Langsdorf) "to give a consistent (i.e., unitary, systematic) presentation of arithmetic, algebra and analysis on the only basis of natural numbers" (Ferreirós, 2007, p. 120-121; cf. Ohm, 1822).

Furthermore, Christian Gottlieb Zimmermann (teacher at the Friedrichswerdersche Gymnasium, in Berlin), ${ }^{10}$ among other points, modified (with Pestalozzi as a reference) ${ }^{11}$ the usual way of explaining the whole and the opposite quantities (praising the works of Karsten and Klügel) in his work on the development of analytical principles (Zimmermann, 1805, p. VIIff.). While Johann Andreas Christian Michelsen (professor at the Berlinischen und Cöllnischen Gymnasium) quoted Kant's idea of the construction of concepts to account for the innovations that he carried out for the

\footnotetext{
${ }^{10}$ Zimmermann was a mathematician that attended the university of Königsberg, where, according to the Allgemeine Deutsche Biographie entry, he became close to Schultz and Kant (Cantor, 1900, p. 251).

${ }^{11}$ A careful analysis of the contributions of Pestalozzi to the "pedagogic techniques of transmission" and the reordering of elementary reckoning textbooks can be found in (Bullynck, 2008).
}

RBHM, Vol. 19, n 37, p. 1-23, 2019 
sake of firmly established and well explained concepts, as those of quantity and variation (Michelsen, 1789, p. VIIff.).

In the Germanic mathematical context of the first decades of the $19^{\text {th }}$ century, Ohm's "program of basing all of mathematics upon the notion of natural number" (the title of his 1822 book was Versuch eines vollkommen consequenten Systems der Mathematik), even though he did not use the expression 'natural numbers' and he "accepted [them] as given objects with their characteristic properties" (Ferreirós, 2007, p. 12), was highly innovative. By contrast, the notion of positive whole numbers that prevailed within the Germanic mathematical tradition during the second half of the $18^{\text {th }}$ century was highly traditional. And yet, as shown, the conceptual tensions around the notion of number got intertwined with pedagogical concerns and new foundational reflections in the late $18^{\text {th }}$ century and the beginning of the $19^{\text {th }}$ century. This precisely paved the way to the forthcoming different approach to natural numbers, to which other factors, such as the consolidation of some educational reforms and the implementation of new ones (cf. Ash, 2006; Fuentes Guillén, 2017), also contributed.

\section{Acknowledgments}

At the 2011 CLMPS, F. William Lawvere asked professor José Ferreirós, my mentor, about the origin of the denomination "natural" numbers. Implicit was that he viewed with suspicion this way of giving precedence to the integers over the real numbers. Why are the reals less natural? That question triggered my interest in the history of the modern conception of natural numbers. A year later, while studying under the supervision of professor Hourya Benis Sinaceur, a phrase from Bolzano reactivated my interest in that topic. I am grateful to both professor Ferreirós and professor Benis Sinaceur for encouraging this work.

\section{Bibliography}

AEPINUS, Franz. 1752. Demonstrationes Primariarum Quarundam Aequationibus Algebraicis Competentium Proprietatum. Rostock: Litteris Adlerianis.

AEPINUS, Franz. 1754. Commentatio de Notione Quantitatis Negativae. Rostock: Johan Jakob Adler.

ASH, Mitchell. 2006. Bachelor of What, Master of Whom? The Humboldt Myth and Historical Transformations of Higher Education in German-Speaking Europe and the US. In: European Journal of Education, vol. 41. 245-267.

VAN ATTEN, Mark. 2012. Kant and Real Numbers. In: DYBJER, LINDSTRÖM, PALMGREN \& SUNDHOLM (eds.). Epistemology versus Ontology. Springer: Dordrecht. 203-213.

VON BÉGUELIN, Nikolaus. 1774. Recherches sur les nombres triangulaires relativement au théoreme général de Mr. Fermat concernant les nombres polygonaux. In: 
Nouveaux Mémoires de l'Académie Royale des Sciences et Belles Lettres. Année MDCCLXXIII. Berlin. 203-215.

BERNOULLI, Jean. 1770. Mémoire sur un probleme de la doctrine du Hazard. In: Mémoires de l'Académie Royale des Sciences et Belles Lettres. Année MDCCLXVIII. Berlin. 384-409.

BÉZOUT, Étienne. 1764/1781. Cours de mathématiques à l'usage des gardes du pavillon et de la marine. Vol. 1. Paris: Pierres.

BÉZOUT, Étienne. 1766. Cours de mathématiques à l'usage des gardes du pavillon et de la marine. Vol. 3. Paris: Musier.

BERNARD, Bolzano. 1804. Betrachtungen über einige Gegenstände der Elementargeometrie. Prague: Karl Barth.

BERNARD, Bolzano. 1810. Beyträge zu einer begründeteren Darstellung der Mathematik. Erste Lieferung. Prague: Caspar Widtmann.

BERNARD, Bolzano. 1816. Der binomische Lehrsatz, und aus Folgerung aus ihm der polynomische, und die Reihen, die zur Berechnung des Logarithmen und Exponentialgrößen dienen, genauer als bisher erwiesen. Prague: C.W. Enders.

BERNARD, Bolzano. 1817a. Die drey Probleme der Rectification, der Complanation und der Cubirung, ohne Betrachtung des unendlich Kleinen, ohne die Annahmen des Archimedes, und ohne irgend eine nicht streng erweisliche Voraussetzung gelöst: zugleich als Probe einer gänzlichen Umstaltung der Raumwissenschaft, allen Mathematikern zur Prüfung vorgelegt. Leipzig: Paul Gotthelf Kummer.

BERNARD, Bolzano. 1817b. Rein analytischer Beweis des Lehrsatzes, dass zwischen je zwey Werthen, die ein entgegensetztes Resultat gewähren, wenigstens eine reele Wurzel der Gleichung liege. Prague: Gottliebe Haase.

BERNARD, Bolzano. 1851. Paradoxien des Unendlichen. Franz Přihonský (Ed.). Leipzig: C. H. Reclam.

BOSSUT, Charles. 1772. Traité élémentaire d'arithmétique. Paris: Jombert.

BOSSUT, Charles. 1773. Traité élémentaire d'algèbre. Paris: Jombert.

DE LA BOTTIÈRE. 1763. Méthode pour résoudre plusieurs Problèmes indéterminés. In: Mémoires de Mathématique et de Physique. Tome Quatrième. Paris: Imprimerie Royale. 33-65.

BULLYNCK, Maarten. 2006. Aspects of 18th Century Mathematical Socialisation. The Case of C.F. Gauss - Materials on the Genesis of the Disquisitiones Arithmeticae, Part I. Available at: https://www.yumpu.com/en/document/view/7783477/aspectsof-18th-century-mathematical-socialisation-kuttakaorg

BULLYNCK, Maarten. 2008. The transmission of numeracy: integrating reckoning in Protestant North-German elementary education (1770-1810). In: Paedagogica Historica, vol. 44, no. 5. 563-585.

BULLYNCK, Maarten. 2013. Stages towards a German mathematical Journal (17501800). In: Archives Internationales d'Histoire des Sciences, vol. 63, n ${ }^{\circ}$ 170-171. 237-251.

BÜTTNER, Christoph. 1754. Erläuterung der Rechenkunst, Geometrie und Trigonometrie. Stettin and Leipzig: Johann Friedrich Kunkel. 
BÜTTNER, Christoph. 1756. Erläuterung der Algebra. Braunschweig: Verlag des grossen Waysenhauses.

CAMUS, Charles. 1749. Cours de mathématique. Élémens d'arithmétique. Vol. 1. Paris: Ballard.

CAMUS, Charles. 1750. Cours de mathématique. Élémens de géométrie théorique et pratique. Vol. 2. Paris: Ballard.

CANTOR, Georg. 1872/1932. Über die Ausdehnung eines Satzes aus der Theorie der trigonometrischen Reihen. In: ZERMELO, Ernst (Ed.). Georg Cantor Gesammenlte Abhandlungen. Mathematischen und Philosophischen Inhlats mit Erläuternden Anmerkungen Sowie mit Ergänzungen aus dem Briefwechsel CantorDedekind. Berlin: Julius Springer. 92-102.

CANTOR, Moritz. 1900. Zimmermann, Christian Gottlieb. In: Allgemeine Deutsche Biographie, vo. 45. 251. Available at: https://www.deutschebiographie.de/pnd117597600.html\#adbcontent

CANTÙ, Paola. 2003. La matematica da scienza delle grandezze a teoria delle forme. L'Ausdehnungslehre di H. Graßmann. PhD thesis. Genova: Università degli Studi di Genova.

CAUCHY, Augustin-Louis. 1821. Cours d'Analyse de l'École Royale Polytechnique. ler Partie. Analyse Algébrique. Paris: Debure frères.

CHAMBERS, Ephraim. 1728. Cyclopadia: or, An Universal Dictionary of Arts and Sciences. Vol. 2. London: James and John Knapton et al.

CONFALONIERI, Sara and KRÖGER, Desirée. 2015. Workshop. Teaching the Mathematical Sciences in France and Germany during the $18^{\text {th }}$ Century: The Case Study of Negative Numbers. In: BARBIN, JANKVIST \& KJELDSEN (Eds.). History and Epistemology in Mathematics Education. Proceedings of the Seventh European Summer University. Denmark: Danish School of Education, Aarhus University. 99-107.

CONFALONIERI, Sara and KRÖGER, Desiree. 2016. Introduction. In: Teaching the Mathematical Sciences at French and German Universities during the $18^{\text {th }}$ Century. Göttingen: Cuvillier Verlag. 1-9. Available at: https://cuvillier.de/uploads/preview/public_file/10107/9783736993440_Leseprobe. pdf

CORRY, Leo. 2015. A Brief History of Numbers. United Kingdom: Oxford University Press.

DARJES, Joachim. 1742. Introductio in Artem Inveniendi seu Logicam TheoreticoPracticam. Jena: Christ. Francisci Buchii.

DARJES, Joachim. 1747. Erste Gründe der gesamten Mathematik, darinnen die HauptTheile so wohl der Theoretischen als auch Praktischen Mathematik. Jena: Christian Heinrich Cuno.

DEDEKIND, Richard. 1888. Was sind und was sollen die Zahlen? Braunschweig: Friedrich Vieweg und Sohn.

DHOMBRES, Jean. 1995. Une conception architecturale des mathématiques: la séparation des variables chez Pfaff. In: Radelet-de Grave and Benvenuto (Eds.). Entre Mécanique et Architecture. Basel: Birkhäuser. 179-203. 
DIDEROT, Denis (Ed.). 1765. Encyclopédie ou Dictionnaire Raisonné des Sciences, des Arts et des Métiers. Tome Onzieme N-Pari. Neufchastel: Samuel Faulche \& Compagnie.

EUCLID. 1908. The Thirteen Books of The Elements. Vol. II, Books III-IX. T. L. Heath (Trans.). Cambridge: Cambridge University Press.

EULER, Leonhard. 1748. Introductio in analysin infinitorum. Tomus Primus. Lausanne: Marcum-Michaelem Bousquet \& Socios.

EULER, Leonhard. 1755. Institutiones calculi differentialis cum eius usu in Analysi Finitorum ac Doctrina Serierim. St. Petersburg: Academiae Imperialis Scientiarum.

EULER, Leonhard. 1766. Recherches sur le mouvement des cordes inégalment grosses. In: Mélanges de Philosophie et de Mathématique de la Société Royale de Turin. Pour les Années 1762-1765. Turin: l'Imprimerie Royale. 27-65.

EULER, Leonhard. 1771. Vollständige Anleitung zur Algebra. Erster Theil. St. Petersburg: Kayserlichen Akademie der Wissenschaften.

EULER, Leonhard. 1774a. Élémens d'algebre. Tome Premier, de l'analyse déterminée. Lyon: Jean-Marie Bruyset, Pere \& Fils.

EULER, Leonhard. 1774b. Élémens d'algebre. Tome Second, de l'analyse indéterminée. Lyon: Jean-Marie Bruyset, Pere \& Fils.

EULER, Leonhard. 1792. L'arithmétique raisonnée et démontrée. Daniel Bernoulli (Trans.) and Lagrange (Ed.). Berlin: Voss \& Fils. et Decker \& Fils.

FERREIRÓS, José. 2007. Labyrinth of Thought. A History of Set Theory and Its Role in Modern Mathematics. $2^{\text {nd }}$ edition. Germany: Birkhäuser.

FUENTES GUILLÉN, Elías. 2017. The Germanic development of the pre-modern notion of number. From c. 1750 to Bolzano's Rein analytischer Beweis. PhD thesis. Salamanca: Universidad de Salamanca.

GAUSS, Carl Friedrich. 1799. Demonstratio nova theorematis omnem functionem algebraicam rationalem integram unius variabilis in factores reales primi vel secundi gradus resolvi posse. Helmstedt: C. G. Fleckeisen.

GAUSS, Carl Friedrich. 1801. Disquisitiones Arithmeticae. Leipzig: Gerhard Fleischer.

GERDIL, Giacinto. 1762. De l'infini absolu considéré dans la grandeur. In: Mélanges de Philosophie et de Mathématique de la Société Royale de Turin. Pour les Années 1760-1761. Turin: l'Imprimerie Royale. 1-45.

GERDIL, Giacinto. 1774. De l'Ordre. In: Mélanges de Philosophie et de Mathématique de la Société Royale de Turin. Pour les Années 1770-1773. Turin: l'Imprimerie Royale. 1-10.

GOLDSTEIN, Catherine and SCHAPPACHER, Norbert. 2006. A Book in Search of a Discipline (1801-1860). In: GOLDSTEIN, SCHAPPACHER \& SCHWERMER (Eds.). The Shaping of Arithmetic. Berlin: Springer. 3-66.

HAUSEN, Christian. 1734. Elementa Matheseos. Pars Prima. Leipzig: officina Marcheana.

HELLWIG, Johann. 1777. Anfangsgründe der allgemeinen Mathematik und der Arithmetik. Braunschweig: Fürstl. Waisenhaus-Buchdruckerey.

JANDERA, Ladislav. 1830. Beiträge zu einer leichteren und gründlicheren Behandlung einiger Lehren der Arithmetik. Prag: Geržabek. 
KÄSTNER, Abraham. 1739. Theoria Radicum in Aequationibus. Leipzig: Breitkopf.

KÄSTNER, Abraham. 1758. Anfangsgründe der Arithmetik, Geometrie, ebenen und sphärischen Trigonometrie und Perspectiv. Göttingen: Witwe Vandenhoeck.

KÄSTNER, Abraham. 1759. Versuch einer Analytischen Abhandlung von den Regelschnitten. Göttingen: Victorinus Bossigel.

KÄSTNER, Abraham. 1761. Anfangsgründe der Analysis des Unendlichen. Göttingen: Wittwe Vandenhoeck.

KÄSTNER, Abraham. 1770. Anfangsgründe der Analysis des Unendlichen. $2^{\text {nd }}$ edition. Göttingen: Wittwe Vandenhoeck.

KÄSTNER, Abraham. 1783. Anfangsgründe der Arithmetik, Algebra, Geometrie, ebenen und sphärischen Trigonometrie, und Prespectiv. Wien: Johann Thomas Edlen von Trattnern.

KÄSTNER, Abraham. 1786a. Anfangsgründe der Arithmetik, Geometrie, ebenen und sphärischen Trigonometrie und Perspectiv. $4^{\text {th }}$ edition. Göttingen: Wittwe Vandenhoeck.

KÄSTNER, Abraham. 1786b. Fortsetzung der Rechenkunst in Anwendungen auf macherley Geschäffte. Göttingen: Wittwe Vandenhoeck.

KÄSTNER, Abraham. 1800. Anfangsgründe der Arithmetik, Geometrie, ebenen und sphärischen Trigonometrie und Perspectiv. $6^{\text {th }}$ edition. Göttingen: Vandenhoeck und Ruprecht.

KARSTEN, Wenceslau. 1756. Matheseos Universalis in usus Auditorum. Rostock: officina Koppiana.

KARSTEN, Wenceslau. 1758. Beyträge zur Aufnahme der Theoretischen Mathematik. Erste Stük. Rostock: Anton Ferdinand Röse.

KARSTEN, Wenceslau. 1760. Mathesis Theoretica Ementaris atque Sublimior. Rostock et Greifswald: Anton Ferdinand Röse.

KARSTEN, Wenceslau. 1767. Lehrbegrif der gesamten Mathematik. Erste Theil. Greifswald: Anton Ferdinand Röse.

KARSTEN, Wenceslau. 1768a. Abhandlungen der Churfürstlich-baierischen Akademie der Wissenschaften. Fünfter Band. München: Churfürstlich-akademischen Buchhandlung.

KARSTEN, Wenceslau. 1768b. Lehrbegrif der gesamten Mathematik. Zweyte Theil. Greifswald: Anton Ferdinand Röse.

KARSTEN, Wenceslau. 1780. Anfangsgründe der Mathematischen Wissenschaften. Die Rechenkunst, Geometrie und ebene Trigonometrie. Erster Band. Greifswald: Anton Ferdinand Röse.

KARSTEN, Wenceslau. 1781. Auszug aus den Anfangsgründen und dem Lehrbegriffe der Mathematischen Wissenschaften. Greifswald: Anton Ferdinand Röse.

KARSTEN, Wenceslau. 1786. Mathematische Abhandlungen. Halle im Magdeburgschen: Rengerschen Buchhandlung.

KLÜGEL, Georg. 1792. Anfangsgründe der Arithmetik, Geometrie und Trigonometrie, nebst ihrer Anwendung auf praktische Rechnungen, das Feldmessen und die Markscheidekunst. $2^{\text {nd }}$ edition. Berlin and Stettin: Friedrich Nicolai. 
KLÜGEL, Georg. 1795a. Über die Lehre von den entgegengesetzten Grössen. In: Archiv der reinen und angewandten Mathematik. Carl Friedrich Hindenburg (Herausgegeber). Erster Band. Leipzig: Schäferischen Buchhandlung. 309-319.

KLÜGEL, Georg. 1795b. Über die Lehre von entgegengesetzten Grössen; Fortsetzung. In: Archiv der reinen und angewandten Mathematik. Carl Friedrich Hindenburg (Herausgegeber). Erster Band. Leipzig: Schäferischen Buchhandlung. 470-481.

KLÜGEL, Georg (Ed.). 1805. Mathematisches Wörterbuch oder Erklärung der Begriff, Lehrsätze, Aufgaben und Methoden der Mathematik. $1^{\text {st }}$ edition. Zweyter Theil, von E bis I. Leipzig: Schwickertschen Verlage.

KLÜGEL, Georg, MOLLWEIDE, Karl Brandan and GRUNERT, Johann August (Eds.). 1831. Mathematisches Wörterbuch oder Erklärung der Begriff, Lehrsätze, Aufgaben und Methoden der Mathematik. Fünfter Theil, von T bis Z. Leipzig: Schwickertschen Verlage.

KNOBLOCH, Eberhard. 1998. Mathematics at the Prussian Academy of Sciences 17001810. In: BEGEHR, KOCH, KRAMER, SCHAPPACHER \& THIELE (Eds.). Mathematics in Berlin. Basel: Springer. 1-8.

DE LACAILLE, Nicolas-Louis. 1741/1756. Leçons élémentaires de mathematiques ou élémens d'algebre et de géométrie. Nouvelle Edition. Paris: H. L. Guerin et L. F. Delatour.

LAGRANGE, Joseph-Louis. 1759. Recherches sur la nature, et la propagation du son. In: Miscellanea Philosophico-Mathematica Societatis Privatae Taurinensis. Tomus Primus. Turin: Typographia Regia. I-112.

LAGRANGE, Joseph-Louis. 1797. Théorie des fonctions analytiques, contenant les principes du calcul différentiel, dégagés de toute considération d'infiniment petits ou d'evanouissans, de limites ou de fluxions, et réduits a l'analyse algébrique des quantités finies. Prairial an V. Paris: Imprimerie de la République.

LAGRANGE, Joseph-Louis. 1770. Additions sur la résolution des équations numériques, imprimé dans le Volume de 1767. In: Histoire de l'Académie Royale des Sciences et Belles-Lettres. Année MDCCLXVIII. Berlin: Haude et Spener. 111-180.

VON LANGSDORF, Karl. 1802. Anfangsgründe der reinen Elementar- und höheren Mathematik. Erlangen: Johann Jakob Palm.

LAPLACE, Pierre-Simon. 1776. Recherches sur l'intégration des Équations différentielles aux différences finies, \& sur leur usage dans la théorie des hasards, \&c. In: Mémoires de Mathématique et de Physique. Année 1773. Paris: l'Imprimerie Royale. 37-231.

LEGENDRE, Adrien Marie. 1798. Essai sur la Théorie des Nombres. Paris: Duprat.

MANCOSU, Paolo. 1996. Philosophy of Mathematics and Mathematical Practice in the Seventeenth Century. USA: Oxford University Press.

MICHELSEN, Johann. 1789. Anleitung zur Buchstabenrechnung und Algebra auch für diejenigen welche der Gelegenheit zum mündlichen Unterrichte beraubt selbige durch eigenen Fleiss erlernen wollen. Erster Theil. Berlin: Siegismund Friedrich Hesse und Compagnie.

NEWTON, Isaac. 1707. Arithmetica universalis sive de compositione et resolutione arithmetica liber. Cantabriga: Tooke. 
OHM, Martin. 1822. Versuch eines vollkommen consequenten Systems der Mathematik. Erster Theil. Berlin: G. Reimer.

PAULSEN, Friedrich. 1906. The German Universities and University Study. Frank Thilly and William W. Elwang (Trans.). New York: Charles Scribner's Sons.

PFAFF, Johann. 1788. Programma inaugurale in quo peculiarem Differentialia Investigandi Rationem ex Theoria Functionum deducit. Helmstedt: Johann Heinrich Kühnlin.

DE PRÉMONTVAL, André-Pierre. 1756. Deux Pieces en forme d'Essais, concernant l'une le Principe de Raison suffisante, \& l'autre la Loi de continuité. In: Histoire de l'Academie Royale des Sciences et Belles-Lettres. Année MDCCLIV. Berlin: Haude et Spener. 418-439.

RALLIER DES OURMES, Jean-Joseph. 1763. Memoire sur les Quarrés magiques. In: Mémoires de Mathématique et de Physique. Tome Quatrième. Paris: l'Imprimerie Royale. 196-241.

RAUPACH, Johann Friedrich. 1815. Die Elemente der Algebra und Analysis, nebst ihrer Anwendung auf die Geometrie. Breslau: Wilhelm Gottlieb Korn.

SALUZZO DI MONESIGLIO, Giuseppe. 1762. Réfléxions pour servir de suite aux mémoires sur le fluide Elastique de la poudre à Canon. In: Mélanges de Philosophie et de Mathématique de la Société Royale de Turin. Pour les Années 1760-1761. Turin: l'Imprimerie Royale. 94-142.

SCHUBRING, Gert. 2005. Conflicts between Generalization, Rigor, and Intuition. Number Concepts Underlying the Development of Analysis in 17-19th Century France and Germany. USA: Springer.

SCHULTZ, Johann. 1788. Versuch einer genauen Theorie des Unendlichen. Vom Unendlichgrossen, und der Messkunst desselben. Erster Theil. Königsberg and Leipzig: Gottlieb Lebrecht Hartung.

SCHULTZ, Johann. 1790. Anfangsgründe der reinen Mathesis. Königsberg: Gottlieb Lebrecht Hartung.

SEGNER, János. 1747. Deutliche und vollständige Vorlesungen über die Rechenkunst und Geometrie. Lemgo: Johann Heinrich Meyer.

SEGNER, János. 1756. Cursus Mathematici, Pars I. Elementa Arithmeticae, Geometriae et Calculi Geometrici. Halle im Magdeburgischen: officina Rengeriana.

SEGNER, János. 1758. Cursus Mathematici, Pars II. Elementa Analyseos Finitorum. Halle im Magdeburgischen: officina Rengeriana.

SEGNER, János. 1767. Deutliche und vollständige Vorlesungen über die Rechenkunst und Geometrie. $2^{\text {nd }}$ edition. Lemgo: Johann Heinrich Meyer.

THIBAUT, Bernhard. 1805. St. Petersburg. In: Göttingische gelehrte anzeigen. 17 Stück, 31 Januar. Göttingen: Heinrich Dieterich. 167-168.

THIBAUT, Bernhard. 1809a. Grundriss der allgemeinen Arithmetik oder Analysis zum Gebrauch bei academischen Vorlesungen entworfen. Göttingen: Heinrich Dieterich.

THIBAUT, Bernhard. 1809b. Grundriss der reinen Mathematik zum Gebrauch bey academischen Vorlesungen abgefasst, Göttingen: Vandenhoeck and Ruprecht. 
WEIERSTRASS, Karl. 1878/1988. Einleitung in die Theorie der analytischen Funktionen. In: ULLRICH (Ed.). Dokumente zur Geschichte der Mathematik. Notes taken by Adolf Hurwitz at Berlin in 1878. Band 4. Braunschweig: Springer.

WOLFF, Christian. 1710. Der Anfangs-Gründe Aller Mathematischen Wissenschafften. Erster Theil. Halle im Magdeburgischen: Johann Gottfried Renger.

WOLFF, Christian. 1713. Elementa Matheseos Universa. Tom. 1. Halle im Magdeburgischen: Renger.

WOLFF, Christian. 1716. Mathematisches Lexicon. Leipzig: Johann Friedrich Gleditschens seel. Sohn.

WOLFF, Christian. 1717. Der Anfangs-Gründe Aller Mathematischen Wissenschaften. Erster Theil. Halle im Magdeburgischen: Rengerischen Buchhandl.

WOLFF, Christian. 1742. Elementa Matheseos Universae. Tom. 1. Halle im Magdeburgischen: officina Libraria Rengeriana.

WOLFF, Christian. 1747. Vollständiges Mathematisches Lexicon. Erster Theil. Leipzig: Gleditschens.

ZEDLER, Johann (Pub.). 1749. Grosses vollständige Universal-Lexicon Aller Wissenschafften und Künste. Band 60, Wur-Zar. Halle und Leipzig: Johann Heinrich Zedler.

ZIMMERMANN, Christian. 1805. Entwickelung analytischer Grundsätze für den ersten Unterricht in der Mathematik besonders für diejenigen, welche sich ohne mündliche Anweisung darüber belehren wollen. Berlin: Heinrich Frölich.

\section{Elías Fuentes Guillén}

Faculty of Sciences - UNAM - Mexico

E-mail: eliasfuentesguillen@gmail.com 